\title{
Hypoglycemic and Hypocholesterolemia Effects of Intragastric Administration of Dried Red Chili Pepper (Capsicum Annum) in Alloxan-Induced Diabetic Male Albino Rats Fed with High-Fat-Diet
}

\author{
Mona Mohamed Abdel Magied*, Nadia Abdel Rahman Salama, Marwa Rashad Ali \\ Department of Food Science, Faculty of Agriculture, Cairo University, Giza, Egypt \\ *Corresponding author:mon_nas_prof_cairo@yahoo.com
}

Received October 17, 2014; Revised October 25, 2014; Accepted October 29, 2014

\begin{abstract}
This study investigated the effect of different drying methods, such as solar drying at $45^{\circ} \mathrm{C}$ and conventional drying at $60^{\circ} \mathrm{C}$ on the quality of red chili pepper for two varieties Serrano and Fresno. The conventional drying method had the highest capsaicin content (2.74 and 1.28\%) for Serrano and Fresno varieties respectively. The effect of dried red chili pepper at 1 and $2 \%$ and the pure capsaicin at $0.015 \%$ were studied in experiments using male albino rats containing 20\% high fat diet (HFD) rendered diabetic with alloxan injection for 4 weeks. The lowest value of blood serum glucose was with G4 "diabetic group fed HFD + 0.015\% capsaicin" that recorded $160 \mathrm{mg} / \mathrm{dl}$. Moreover, serum cholesterol as well as serum triglycerides for the diabetic groups G4 and also G6 that "fed HFD + 2\% Serrano red dried chili pepper" were significantly low. The HDL concentration for the groups G4 and G6 were significantly higher than the G3 "diabetic rats fed with HFD". Feeding the groups of diabetic rats with HFD +1 or $2 \%$ dried red chili pepper or $0.015 \%$ capsaicin, the LDL and VLDL levels as well as total lipids were significantly low as compared with control diabetic HFD "G3".
\end{abstract}

Keywords: red chili, Capsicum annum, drying, type 2 diabetes, cholesterol, high fat diet, rats

Cite This Article: Mona Mohamed Abdel Magied, Nadia Abdel Rahman Salama, and Marwa Rashad Ali, "Hypoglycemic and Hypocholesterolemia Effects of Intragastric Administration of Dried Red Chili Pepper (Capsicum Annum) in Alloxan-Induced Diabetic Male Albino Rats Fed with High-Fat-Diet.” Journal of Food and Nutrition Research, vol. 2, no. 11 (2014): 850-856. doi: 10.12691/jfnr-2-11-15.

\section{Introduction}

The word pepper describes two different kinds of plants from two unlike species mainly used as spices and seasoning in foods. Thus the genus Piper Nigrumwhich is a flowering vine of the Piperaceae family and Capsicum which is a genus of plants of the Solanaceae family native to Mexico but currently cultivated in Asia, Africa and countries along the Mediterranean (Yao et al., 1994; InKyung et al., 2007). The genus capsicum includes five main species: C. annuum (Containing Jalapeno, Serrano, Bell and annuum varieties), C. Frutescens (Containing the Tabasco variety), C. chinense (Containing the Habanero and Scotch Bonnet varieties). C. baccatum (Containing Aji variety) and C. pubescens (Containing the Rocoto and Manzano varieties) (Pino et al., 2006). The Fresno chili pepper is a Jalapeño style chili, but hotter than most Jalapeños. The peppers ripen from green to red. The plants do well in warm to hot temperatures and dry climates with long sunny summer days and cool nights. They are very cold-sensitive, but disease resistant reaching a height of 24 to 30 inches (Bonnie Plants, 2014). The Serrano pepper is a type of chili pepper that originated in the mountainous regions of the Mexican. The name of the pepper is a reference to the mountains (sierras) of these regions (Dave et al., 2009). The fruit can be harvested while they are green or ripe. Unripe Serrano peppers are green, but the color at maturity varies. Common colors are green, red, brown, orange, or yellow. Serrano peppers do better in soils with a pH between 7.0 and 8.5 and in warm temperatures above $75^{\circ} \mathrm{F}\left(24^{\circ} \mathrm{C}\right)$; they are not frost tolerant (Kurt 2012).

Traditionally, fresh chilies are preserved by drying immediately after harvest under the sun without any special treatment, and this remains the most widely practiced method throughout the producing countries. In this method, drying cannot be controlled and a relatively low quality dried product is obtained. Drying rate is very slow and takes 7-15 days, depending on the weather conditions (Hossain, 2003). Currently, conventional drying is popular for drying chili due to a relatively short drying time, uniform heating, more hygienic characteristics and improves some of the quality factors of the dried product (Kostaropoulos and Saravacos 1995; Maskan et al. 2002). The temperature ranges from 45 to $70^{\circ} \mathrm{C}$ and this reduces drying time to less than $20 \mathrm{hrs}$ (Toontom., et al 2012). However, using high temperatures for drying produces a low quality of chili, with losses of 
volatile compounds, nutrients and color (Di Scala and Crapiste, 2008; Kaleemullah and Kailappan, 2006).

Avery unique characteristics of chili is the spiciness which comes from the chemical substance called capsaicin. Chili can be grown all year round. The conventional method to preserve the chili is dried up under the sun by spreading the chili in the large open area (Kaleemallah and Kailappan 2005). As an alternative to conventional sun drying, solar drying is a promising alternative for drying chili, because mechanical drying is mainly used in industrial countries and is not applicable to small farms in developing countries due to high investment and operating costs (Hossain and bala 2007).

Pungency is the main feature of chili peppers and depends on the presence of a group of alkaloids belong to the family of capsaicinoids. Those molecules are synthesized in the interlocular septum and consequently the portion of the fruit richer in capsaicicinoids is the placental tissue (Prasad et al, 2006). Capsaicin and deyhydrocapsicin are the predominant molecules, representing about the $90 \%$ of the total capsaicinoids, and usually their amount is determined for pungency characterization (Giuffrida et al., 2013). The amount of capsaicin in a given variety can vary depending on the light intensity and temperature at which the plant is grown, the age of the fruit, and the position of the fruit on the plant. The first test developed to measure pungency was the Scoville test, first developed in 1912 by Wilbur Scoville (Scoville 1912). There are five levels of pungency classified using Scoville heat units (SHU): nonpungent (0-700 SHU), mildly pungent (700-3,000 SHU), moderately pungent (3,000-25,000 SHU), highly pungent (25,000-70,000 SHU) and very highly pungent (>80,000 SHU) (Weiss 2002).

Capsaicinoids confer to the barriers the well known characteristic of spicy flavor that make chili peppers highly consumed all over the world as flavoring and additive to many kind of foods. Many biological effects and in the late years important pharmaceutical properties, including antioxidant, anticarcinogenics, ant-inflammatory effects have been recognized to those alkaloids (ReyesEscogido et al., 2011). The determination of the pungency degree is very important for consumers and for industrial purposes, since a defined value is required to be employed as ingredient for food production. The perception of pungency is variable between different individuals and seems to be also affected by the habit (Rozin et al 1981).

Diabetes mellitus is a metabolic disorder characterized by hyperglycemia and alterations in carbohydrate, lipid and protein metabolism, associated with absolute or relative deficiencies in insulin secretion and / or insulin action (Tundis et al 2012). The world health organization (WHO) estimates that more than 220 million people worldwide have diabetes and this number is likely to more than double by 2030 (WHO, 2009). Several works demonstrated the ability of pepper and their constituents to influence the blood glucose level (Chaiyasit et al 2009; Oboh et al 2011and Tundis et al 2011). Moreover, the capsaicin of red pepper (Capsicum annuum) had significant hypolipidemic influence in a variety of experimental animal system (Srinivsan et al 2004). Manjunatha and Srinivsan (2006) reported the beneficial influences of dietary capsaicin on the susceptibility of low density lipoprotein (LDL) to oxidation.
The objective of this work was to study the effect of different methods of drying on the chemical composition and capsaicin content of two varieties of red chili pepper and to examine the effect of red chili pepper powder on serum blood glucose and the LDL of diabetes and hypercholesterolemic rats

\section{Materials and Methods}

\subsection{Materials}

Two varieties of fresh red chili pepper (Capsicum annum, L.) "Serrano and Fresno" were harvested from a green house in the Gaara farm, located in Masr Ismalia, Egypt, in June 2013 at their full maturity and were packaged in perforated plastic bags stored in the refrigerator at $5^{\circ} \mathrm{C}$ until analysis. The samples were authenticated by Prof. Hassan Ali, Vegetable Crop Department, Faculty of Agriculture, Cairo University, Egypt. Analytical-grade ethyl alcohol (99.8\%) was purchased from El Nasr Pharmaceutical chemical Company. Capsaicin (>95\%) was purchased from Sigma Aldrich company. Forty eight male Albino rats weighing 160-175 g were purchased from the Research Institute of Ophthalmology, Giza, Egypt. Diagnostic kits were purchased from Bio-Diagnostics Company, Giza, Egypt. Alloxan monohydrate was purchased from Kemet Medical Company, Cairo, Egypt.

\subsection{Preparation of Dried Red Chili Pepper}

Drying of red chili pepper was conducted either by solar drying at $45^{\circ} \mathrm{C}$ for 75 hours or by conventional drying in a cabinet dryer (DRTH) pilot plant, Engineering 86 Equipment GmbH, 6072 Dreieich West Germany at $60^{\circ} \mathrm{C}$ for 27 hour. The dried samples were packed into plastic bags and stored at room temperature $\left(25^{\circ} \mathrm{C}\right)$ until analysis.

\subsection{Determination of Chemical Composition of Fresh and Dried Chili Samples}

All the Analyses were performed in duplicate to determine the moisture content, ash, total carbohydrate, protein, crude fiber and fat as described by the (AOAC, 2005).

\subsection{Extraction of Capsaicin}

Soxhlet extraction [995.03] was used as exhaustive extraction as described in AOAC (2005). Approximately $500 \mathrm{mg}$ of dry pepper (powder) and $5 \mathrm{~g}$ of fresh red chili pepper were weighted and placed in a soxhlet apparatus with $50 \mathrm{~mL}$ of ethanol. The solution was gently refluxed for $3 \mathrm{~h}$ and allowed to cool, then filtered the solution through Whatman No. 4 filter paper; evaporating to dryness in a rotary evaporator system then transferred to 5 ml volumetric flask. Capsaicin was analyzed by HPLC technique as described by Juangsamoot, et al, (2012) using standard capsaicin.

\subsection{Scoville Heat Unit Conversions}

Chili pungency is measured in Scoville Heat Units (SHU) corresponding to the concentration of capsaicinoids. 
The pungency level in SHU was calculated by using the content of capsaicin (\%dry weight) X 150,000 (Govindarajan, 1986).

\subsection{Biological Experimental}

Forty eight male Albino rats weighing 160-175 g were obtained from Research Institute of Ophthalmology, Giza,
Egypt. The animals were housed individually in well aerated cages with screen bottom and fed on basal diet as described in A. O.A.C (2000) for 12 days as an adaptation period. Salt mixture and vitamin mixture were prepared as described in A.O.A.C (1995 and 2000) respectively. Temperature and humidity were maintained at $25^{\circ} \mathrm{C}$ and $60 \%$ respectively, food and water were given ad libitum.

Table 1. Composition of basal and HF diets (g/100g diet)

\begin{tabular}{|c|c|c|c|c|c|c|c|c|}
\hline Ingredient & $\begin{array}{c}\text { (G1) } \\
\text { Basal } \\
\text { diet } \\
\text { control }\end{array}$ & $\begin{array}{c}\text { (G2) } \\
\text { HFD } \\
\text { control }\end{array}$ & $\begin{array}{c}\text { (G3) } \\
\text { HFD } \\
\text { diabetic } \\
\text { rats } \\
\end{array}$ & $\begin{array}{c}\text { (G4) } \\
\text { HFD diabetic } \\
+0.015 \% \\
\text { capsaicin }\end{array}$ & $\begin{array}{c}\text { (G5) } \\
\text { HFD diabetic } \\
+1 \% \text { Serrano } \\
\text { pepper }\end{array}$ & $\begin{array}{c}\text { (G6) } \\
\text { HFD diabetic } \\
+2 \% \text { Serrano } \\
\text { pepper }\end{array}$ & $\begin{array}{c}\text { (G7) } \\
\text { HFD diabetic } \\
+1 \% \text { Fresno } \\
\text { Pepper }\end{array}$ & $\begin{array}{c}\text { (G8) } \\
\text { HFD diabetic } \\
+2 \% \text { Fresno } \\
\text { Pepper } \\
\end{array}$ \\
\hline Starch & 62 & 39.62 & 39.62 & 39.61 & 38.62 & 37.62 & 38.62 & 37.62 \\
\hline Casein* & 18 & 18 & 18 & 18 & 18 & 18 & 18 & 18 \\
\hline Sucrose & - & 10 & 10 & 10 & 10 & 10 & 10 & 10 \\
\hline Beef Tallow & - & 20 & 20 & 20 & 20 & 20 & 20 & 20 \\
\hline Corn oil & 10 & 2 & 2 & 2 & 2 & 2 & 2 & 2 \\
\hline Cellulose & 5 & 5 & 5 & 5 & 5 & 5 & 5 & 5 \\
\hline Vit- Mix & 1 & 1 & 1 & 1 & 1 & 1 & 1 & 1 \\
\hline Salt-Mix & 4 & 4 & 4 & 4 & 4 & 4 & 4 & 4 \\
\hline Cholin bitartarate & - & 0.20 & 0.20 & 0.20 & 0.20 & 0.20 & 0.20 & 0.20 \\
\hline Cholic acid & - & 0.18 & 0.18 & 0.18 & 0.18 & 0.18 & 0.18 & 0.18 \\
\hline Red Chili pepper & - & - & - & - & 1.0 & 2.0 & 1.0 & 2.0 \\
\hline
\end{tabular}

* Casein contained $83.33 \%$ protein.

\subsubsection{Experimental Design}

The rats (48 rats) were divided into 8 groups, each contain 6 rats, namely: (G1) Control basal diet, the rest of the groups were fed with high fat diet (HFD) for two weeks. The previous mentioned groups were named as (G2) control fed HFD, (G3) control fed HFD of the diabetic rats, (G4) HFD of diabetic rats and administrated orally (by stomach tube) $0.015 \%$ of capsaicin pure. The groups of rats G5, G6, G7 and G8 were fed with HFD + $1 \%$ or $2 \%$ of dried Serrano or dried Fresno chili red pepper respectively as described by Islam and Choi, (2008). The groups of experimental rats are shown in Table 1. After 2 weeks feeding of HFD, diabetes was induced in overnight fasted animals by a single intraperitoneal injection of alloxan monohydrate dissolved in $5 \% \mathrm{w} / \mathrm{v}$ normal saline at a dose of $150 \mathrm{mg} / \mathrm{kg} \mathrm{BW}$. The dose of alloxan was injected per periodically for 3 days. Five days later, blood samples were collected from the eye plexuser by a fin capillary glass tube. The samples were centrifuged for $10 \mathrm{~min}$ at $3000 \mathrm{rpm}$ and the serum was collected, blood glucose level was measured. The rats with blood glucose level $\geq 300 \mathrm{mg} / \mathrm{dL}$ were considered to be diabetic as recommended by Islam and Choi, (2008). Serum total cholesterol, HDL and LDL - cholesterol, triglycerides (TG), and total lipids. All the analyses were determined photometrically by using the diagnostic kits. At the end of the experiment (4 weeks), the blood was sampled for the previous mentioned analysis.

\section{Statistical Analysis}

Results were statistically analyzed by the least significant differences (L.S.D) at the level of probability procedure according to Snedecor and Cochran, (1980).

\section{Result and Discussion}

\subsection{Effect of Drying Methods on Vhemical Properties of Red Chili Pepper}

The chemical composition of fresh as well as dried red chili pepper is shown in Table 2. Results show that the moisture content of the two varieties of fresh red chili pepper "Serrano and Fresno" was $84.3 \%$ and $86.06 \%$ respectively. The moisture content of the solar dried red chili pepper of the two different varieties Serrano or Fresno 8.46 and $7.71 \%$ respectively. However, the moisture content of the conventional dried red chili pepper for Serrano and Fresno were 8.24 and $7.20 \%$ respectively. There results are in accordance with the results of Wall and Bosland (1993) who found that moisture content of red chili pepper at $8 \%$ is ideal. They also added that, moisture content above $11 \%$ allows mould to grow and moisture content below 4\% causes an excessive color loss. Moreover, Yaldiz et al (2010) reported that, the moisture content of dried chili pepper by solar drying was in the average of $8.22 \%$, meanwhile it reached up to $7.27 \%$ for the conventional drying method at $60^{\circ} \mathrm{C}$.

Results in Table 2 also show the ash content of different tested samples. So, the application of drying significantly increased the dry matter and ash values due to the removal of water from the peppers. Our results are in agreement with the results of Ozgur, et al., (2011). Results in Table 2 also show the carbohydrate content of different tested samples. No significant different could be shown between the two different dried methods (solar or conventional drying) for the two varieties of red dried chili pepper either for Serrano or Fresno. These results are in agreement with the results of Esayas et al., (2011) and Sarker et al., (2012). Moreover, results in Table 2 show 
that the protein content for Serrano variety either dried with solar or conventional drying method were 12.31 and $12.35 \%$ respectively, they were in nonsignificant difference. The same results were also showed for the
Fresno variety; they were recorded 13.40 and $13.66 \%$ for solar conventional drying methods respectively. Our results are in accordance with the results of Tunde Akintude (2010).

Table 2. Chemical composition of the two varieties (Serrano and Fresno) of (Capsicum annuum L.) on dry weight basis

\begin{tabular}{|c|c|c|c|c|c|c|c|c|}
\hline \multirow{3}{*}{$\begin{array}{c}\text { Chemical } \\
\text { composition \% }\end{array}$} & \multicolumn{8}{|c|}{ Varieties of red chili pepper } \\
\hline & \multicolumn{4}{|c|}{ Serrano } & \multicolumn{4}{|c|}{ Fresno } \\
\hline & $\begin{array}{l}\text { Fresh (on dry } \\
\text { weight) }\end{array}$ & $\begin{array}{l}\text { Solar drying } \\
\quad\left(45^{\circ} \mathrm{C}\right)\end{array}$ & $\begin{array}{l}\text { Conventional } \\
\text { drying }\left(60^{\circ} \mathrm{C}\right)\end{array}$ & $\begin{array}{c}\text { LSD } \\
\text { at } \\
5 \%\end{array}$ & $\begin{array}{l}\text { Fresh (on } \\
\text { dry weight) }\end{array}$ & $\begin{array}{l}\text { Solar drying } \\
\left(45^{\circ} \mathrm{C}\right)\end{array}$ & $\begin{array}{l}\text { Conventional } \\
\text { drying }\left(60^{\circ} \mathrm{C}\right)\end{array}$ & $\begin{array}{c}\text { LSD } \\
\text { at } \\
5 \%\end{array}$ \\
\hline $\begin{array}{l}\text { Total } \\
\text { Carbohydrate }\end{array}$ & $67.44 \pm 0.108^{\mathrm{a}}$ & $61.52 \pm 0.002^{\mathrm{b}}$ & $61.55 \pm 0.002^{b}$ & 0.008 & $68.73 \pm .063^{\mathrm{a}}$ & $63.29 \pm 0.031^{\mathrm{b}}$ & $63.20 \pm 0.004^{b}$ & 0.770 \\
\hline Crude Protein & $13.79 \pm 0.002^{\mathrm{a}}$ & $12.31 \pm 0.006^{b}$ & $12.35 \pm 0.002^{b}$ & 0.405 & $14.51 \pm .006^{\mathrm{a}}$ & $13.40 \pm 0.001^{b}$ & $13.66 \pm 0.113^{b}$ & 0.009 \\
\hline Ash & $4.50 \pm 0.007^{\mathrm{a}}$ & $4.15 \pm 0.001^{b}$ & $4.21 \pm 0.035^{b}$ & 0.133 & $4.00 \pm 0.141^{\mathrm{a}}$ & $3.55 \pm 0.004^{b}$ & $3.69 \pm 0.002^{\mathrm{b}}$ & 0.429 \\
\hline Fat & $7.90 \pm 0.064^{\mathrm{a}}$ & $7.44 \pm 0.184^{\mathrm{a}}$ & $7.50 \pm 0.106^{\mathrm{a}}$ & 0 & $5.78 \pm 0.001^{\mathrm{a}}$ & $5.33 \pm 0.005^{\mathrm{a}}$ & $5.39 \pm 0.001^{\mathrm{a}}$ & 0 \\
\hline Crude Fiber & $6.37 \pm 0.003^{\mathrm{a}}$ & $6.12 \pm 0.001^{\mathrm{a}}$ & $6.15 \pm 0.007^{\mathrm{a}}$ & 0 & $6.98 \pm 0.007^{\mathrm{a}}$ & $6.72 \pm 0.003^{\mathrm{a}}$ & $6.86 \pm 0.005^{\mathrm{a}}$ & 0 \\
\hline Moisture & $84.35 \pm 0.063^{\mathrm{a}}$ & $8.460 .004^{b}$ & $8.24 \pm 0.001^{\mathrm{C}}$ & 0.128 & $86.06 \pm .001^{\mathrm{a}}$ & $7.71 \pm 0.002^{b}$ & $7.20 \pm 0.021^{\mathrm{c}}$ & 0.213 \\
\hline
\end{tabular}

The fat content of the different tested samples of red chili pepper is shown in Table 2 results show that the fat content for the Serrano or Fresno varieties were in non significant difference for solar or conventional drying methods as well as for the fresh sample (on dry weight basis). Famurewa et al., (2006) found that the fat content of dried red chili pepper was in the range of 11.38 to $11.60 \%$. The crude fiber content of red chili pepper is shown in Table 2. No significant difference was their between the different tested samples either for Serrano or Fresno varieties. So, different treatments of drying did not affect on the crude fiber comparing with the corresponded fresh sample (on dry weight basis), they were in the range of 6.37 to $6.98 \%$. Our results were not accomplished with the results of Famurewa et al., (2006) who found that, the amount of crude fiber in red chili pepper was only $0.67 \%$.

\subsection{Effect of Drying Method on Capsaicin Content and Scoville Heat Units of Red Chili Pepper}

The capsaicin content and the scoville heat units of fresh as well as the dried red chili pepper for the two varieties Serrano and Fresno are shown in Table 3. Results show that the capsaicin content of fresh samples was recorded 0.23 and $0.17(\mathrm{~g} / 100 \mathrm{~g})$ for the two varieties Serrano and Fresno respectively. Meanwhile, the dried samples recorded $1.64,0.40 \%$ capsaicin of solar drying method at $45^{\circ} \mathrm{C}$ for Serrano and Fresno varieties respectively. Moreover, the capsaicin content of dried red chili pepper by conventional drying at $60^{\circ} \mathrm{C}$ was recorded 2.74 and $1.28 \%$ respectively. Yaldiz et al., (2010) reported that the capsaicin content of red chili (Capsicum frutescens) varied between 0.50 and $4.20 \%$ they attributed this due to temperature, time and drying methods. Topuz and Ozdemir (2004) reported that sun-dried Turkish paprika chili that was processed for 5-7 days lost $24.6 \%$ of the capsaicin content. They also added that, oven - dried Turkish paprika chili that was dehydrated at $70^{\circ} \mathrm{C}$ for 90 min, lost $21.5 \%$ of the capsaicin content.

Table 3. Effect of drying method on capsaicin content and scoville heat units of red chili pepper

\begin{tabular}{|c|c|c|c|c|}
\hline \multirow{2}{*}{ Samples of red chili pepper } & \multicolumn{2}{|c|}{ Capsaicin\% } & \multicolumn{2}{|c|}{ SHU $^{\mathbf{a}}$} \\
\hline & Serrano & Fresno & Serrano & Fresno \\
\hline Fresh & $0.23^{\mathrm{c}}$ & $0.17^{\mathrm{c}}$ & $34500^{c}$ & $25500^{c}$ \\
\hline Solar drying $\left(45^{\circ} \mathrm{C}\right)$ & $1.64^{b}$ & $0.40^{\mathrm{b}}$ & $24600^{b}$ & $60000^{b}$ \\
\hline Conventional drying $\left(60^{\circ} \mathrm{C}\right)$ & $2.74^{\mathrm{a}}$ & $1.28^{\mathrm{a}}$ & $411000^{\mathrm{a}}$ & $192000^{\mathrm{a}}$ \\
\hline LSD at 5\% & 0.01847 & 0.02247 & 3.67426 & 2.25001 \\
\hline
\end{tabular}

${ }^{\mathbf{a}}$ SHU $=$ The content of capsaicin (\% dry weight) $\mathrm{x} 150,000$

It could be show also from the results in Table 3 the hotness "SHU" of the red chili pepper for the two varieties Serrano and Fresno either fresh or dried were varied according to the variety and also to the used drying method. These values of SHU were in the range of 34500 to 411000 and 25500 to 192000 for Serrano and Fresno varieties respectively. These results are in accordance with the results of Toontom et al (2012), who found that the hotness (SHU) of fresh and dried red chili pepper was in the range of 14000 to 314000 SHU depending of the variety and the drying method. Moreover, Topuz (2002) found that the pungent components of red pepper flakes were higher in oven - dried samples compared to sun dried samples. Giuffrida et al (2013) found that Serrano variety of fresh red chili pepper had 22000 SHU.

\subsection{Biological Evaluation of Red Chili Peppers and Capsaicin}

\subsubsection{Food intake and Gain in Body Weight}

Food intake (g/rat/day) and body weight gain (\%) of the different tested groups of rats fed without or with red chili pepper as well as capsaicin are shown in Table 4. Results show the significant difference through out the experiments, the highest food intake was recorded for the control group of rats fed with HFD (G2). In contrast the lowest food intake was with the G3 that recorded $14.43 \mathrm{~g}$ /rat /day. Moreover, the diabetic groups of rat fed with HFD with $2 \%$ Serrano or Fresno had less food intake than the corresponded groups fed with $1 \%$ only, they were in significant difference. Results also show the significancy of body weight gain (\%) among the different tested groups of rats. The highest body weight gain was with the G2 "HFD control", the lowest value was with groups G3 "HFD diabetic rats". Among the group of rats, G4, G5, G6, G7 AND G8 recorded low values of body weight gain comparing with G2, however, G4 had the lowest value 
(26.97\%) among these groups. These results are in agreement with the results of Liang et al (2013) and Islam and Choi (2008) and Anthony et al (2013) who found some decrease in body weight of the Wister rats in the treated groups (diabetic control). They also added that, on increase in body weight was observed when the treated groups were compared to the diabetic control groups. In addition, Yoshioka et al (2010) reported that, the red pepper has been found to aid the rate of burning; however, in a diabetic state it can actually reduce the rate of loss of the body protein (muscles). All these authors reported that, capsaicin is the chemical in chili peppers that contributes to their spiciness, capsaicin stimulates a receptor found in sensory neurons, creating the heat sensation and subsequent reaction like redness and sweating.

Table 4. Food intake and body weight gain of rats fed with different levels of red chili pepper "Serrano and Fresno"

\begin{tabular}{|l|c|c|}
\hline \multicolumn{1}{|c|}{ Experimental groups of rats } & Food intake g/rat/day & Body weight gain\% \\
\hline G1: Basal diet control & $17.70 \pm 0.0707^{\mathrm{e}}$ & $25.87 \pm 0.0072^{\mathrm{g}}$ \\
\hline G2: HFD control & $20.58 \pm 0.0014^{\mathrm{a}}$ & $38.25 \pm 0.0072^{\mathrm{a}}$ \\
\hline G3: HFD diabetic rats & $14.43 \pm 0.0014^{\mathrm{f}}$ & $11.03 \pm 0.0049^{\mathrm{h}}$ \\
\hline G4: HFD diabetic + 0.015\% capsaicin & $18.16 \pm 0.0014^{\mathrm{de}}$ & $26.97 \pm 0.0707^{\mathrm{f}}$ \\
\hline G5: HFD diabetic + 1\% Serrano pepper & $19.29 \pm 0.078^{\mathrm{c}}$ & $35.37 \pm 0.0072^{\mathrm{c}}$ \\
\hline G6: HFD diabetic + 2\% Serrano pepper & $18.29 \pm 0.078^{\mathrm{d}}$ & $27.44 \pm 0.0072^{\mathrm{e}}$ \\
\hline G7: HFD diabetic + 1\% Fresno Pepper & $19.93 \pm 0.0156^{\mathrm{b}}$ & $37.51 \pm 0.0061^{\mathrm{b}}$ \\
\hline G8: HFD diabetic + 2\% Fresno Pepper & $19.17 \pm 0.0014^{\mathrm{c}}$ & $34.72 \pm 0.0056^{\mathrm{d}}$ \\
\hline \multicolumn{1}{|c|}{ LSD at 5\% } & $\mathbf{0 . 5 3 5 3}$ & $\mathbf{0 . 1 5 2 8}$ \\
\hline
\end{tabular}

4.3.2. Influence of Dietary Red Chili Pepper and capsaicin on lowering LDL and VLDL. The dietary Capsaicin on Serum and Lipid Profile

The results of the serum biochemical parameters for different groups of experimental rats are shown in Table 5. Serum glucose $(\mathrm{mg} / \mathrm{dl})$ after four weeks for all the tested rats was in significant difference, the lowest value was with G1 "control basal diet", group 4 "G4" of rats that had HFD that submit to diabetic case and also had $0.015 \%$ capsaicin was recorded less serum glucose than G3 that hadn't capsaicin, also G6 of rats which had HFD under diabetic condition $+2 \%$ Serrano chili pepper was in non significant difference with G4 and G3. results also show that G5 and G8 were in non significant difference, this indicate that the powerful of $1 \%$ Serrano pepper was higher than $2 \%$ Fresno pepper as lowering serum glucose.

Serum cholesterol $(\mathrm{mg} / \mathrm{dl})$ of experimental groups of rats after four weeks significantly low as a results of fed $0.015 \%$ capsaicin "G4" that contain HFD for the diabetic rats, the decreasment was also observed for the "G6" of diabetic rats which fed HFD $+2 \%$ Serrano red chili pepper companying with G2 and G3. Obviously, the lowest value of serum cholesterol was with "G1" group of rats fed control basal diet. No significant difference could be shown among the group of rats named as G5, G7 and G8. the serum triglycerides (mg/dl) level for the groups of rats after four weeks was significantly lowered for G4, G5, G6 and G8 of the rats which fed HFD + $0.015 \%$ capsaicin, HFD + 1\% Serrano, HFD + 2\% Serrano and HFD + 2\% Fresno red chili pepper respectively.

At the end of the experiment (4 weeks), the HDL concentrations $\mathrm{mg} / \mathrm{dl}$ for the groups of diabetic rats fed with HFD + 0.015\% capsaicin "G4" and "G6" fed HFD $+2 \%$ Serrano pepper were significantly higher than the "G3" diabetic rats fed with HFD. However, no significant difference could be shown between "G2" HFD control and all the other groups of diabetic rats either fed with red chili pepper or $0.015 \%$ capsaicin. The serum LDL (mg/dl) and VLDL (mg/dl) levels for the "G1" control basal diet after four week was recorded the lowest value. In contrast, the highest value was with "G3" the group of diabetic rats fed with HFD. As a result of feeding the other group of diabetic rats with HFD +1 or $2 \%$ red chili pepper for the two varieties Serrano and Fresno, the LDL and VLDL levels were significantly lowered as compared with "G3". So, this shows the effect of red chili pepper as well as capsaicin treatment "G4" of diabetic groups of rats and also all the other diabetic groups of rats fed with HFD +1 or2\% Serrano or Fresno red chili pepper for four weeks recorded low serum total lipids (mg/dl) compared with "G3" diabetic rats fed with HFD.

The administered Capsicum frutescence in the diet at 1 $\mathrm{g}$ and $2 \mathrm{~g}$ doses significantly reduced the blood glucose level, total cholesterol compared with diabetic control (Anthony et al 2013) they also attributed this significant reduction in blood glucose level to the presence of hypoglycemic agents in red chili pepper. Moreover, pharmacokinetic and effect of capsaicin in red chili pepper on decreasing plasma glucose level in a study of 12 healthy volunteers by receiving $5 \mathrm{~g}$ of capsicum had been documented (Kamon et al 2009). In addition, Anthony, et al (2013), concluded that, the increase in serum total cholesterol, serum blood glucose and reduction in serum high density lipoprotein (HDL) associated with alloxan induced diabetes mellitus were reversed after treatment with $1 \mathrm{~g}$ and $2 \mathrm{~g}$ Capsicum frutescence supplemented diet. So, they recommended that red chili pepper be added as spices to the food of obese individual as well as diabetic patients for its hypoglycemic properties, including of increase energy utilization as well as being Cardioprotective by its effect on plasma lipids. Manjunatha and Srinivasan (2007) show that dietary capsaicin significantly countered hypercholesterolemic brought about by high cholesterol feeding. The reduction in blood cholesterol brought about by dietary spice principles was mainly in the LDL, VLDL fractions.

Reduction in serum cholesterol levels in rats on a normal 10\% fat diet incorporated with 1.5, 3 and $15 \mathrm{mg} \%$ capsaicin as reported by Sambaiah et al (1978). Moreover, lowered liver cholesterol in induced hypercholesterolemic by Sambaiah and Satyanarayana (1980). Fecal excretion of cholesterol and bile acids was enhanced in animals fed capsaicin in these studies. In a subchronic toxicity study in rats administered, $50 \mathrm{mg} / \mathrm{kg}$ per day of capaicin for 60 days, plasma cholesterol levels were significantly reduced a long with triglycerides and phospholipids (Monsereenusorn, 1983). Negulesco et al. (1987) have observed that administration of $8 \mathrm{mg}$ capsaicin/day for 35 days to rabbits on a $0.5 \%$ cholesterol diet produced a beneficial lowering of plasma cholesterol and triglycerides. 
Young turkeys on a 2-3 mg capsaicin/kg feed for 9 days along with $0.5 \%$ cholesterol had lower total serum cholesterol than controls (Negulesco and Murnane 1982). Recently, the anti-hypercholesterolemic efficacy of dietary capsaicin has been shown in rats fed an atherogenic high cholesterol diet which resulted in countering of the changes in the membrane lipid profile in the erythrocytes (Kempaiah and Srinivasan 2002).

\section{Conclusions}

In conclusion, study on health benefits of red chili pepper bioactive constituent has attracted the interest of scientists seeking to prevent disease and promote health. In this context the present study evaluated the effect of different drying methods on chemical composition and capsaicin content, as well as hypoglycemic and hypocholesterolemic properties of two different varieties of dried red chili pepper "Serrano and Fresno". The conventional drying had high content of capsaicin for Serrano and Fresno varieties than solar drying. Serum level of glucose, cholesterol and triglycerides in rats fed HFD associated with alloaxn induced diabetes mellitus were reversed after treatment with $2 \mathrm{~g}$ of Serrano and $0.015 \%$ capsaicin. Therefore it could be recommended that red chili pepper could be used for diabetic patients.

\section{Competing Interests}

Authors have declared that no competing interests exist.

Table 5. Influence of dietary red chili pepper and capsaicin on serum and lipid profile

\begin{tabular}{|c|c|c|c|c|c|c|c|c|c|c|c|c|c|c|}
\hline \multirow{3}{*}{$\begin{array}{l}\text { Experimental } \\
\text { groups of rats }\end{array}$} & \multicolumn{14}{|c|}{ Biochemical parameters } \\
\hline & \multicolumn{2}{|c|}{$\begin{array}{l}\text { Serum glucose } \\
(\mathbf{m g} / \mathbf{d l})\end{array}$} & \multicolumn{2}{|c|}{$\begin{array}{c}\text { Serum cholesterol } \\
\text { (mg/dl) }\end{array}$} & \multicolumn{2}{|c|}{ Serum TG (mg/dl) } & \multicolumn{2}{|c|}{$\begin{array}{c}\text { Serum HDL } \\
\text { (mg/dl) }\end{array}$} & \multicolumn{2}{|c|}{$\begin{array}{c}\text { Serum LDL } \\
(\mathrm{mg} / \mathrm{dl})\end{array}$} & \multicolumn{2}{|c|}{$\begin{array}{c}\text { Serum VLDL } \\
\text { (mg/dl) }\end{array}$} & \multicolumn{2}{|c|}{$\begin{array}{c}\text { Serum Total lipids } \\
\text { (mg/dl) }\end{array}$} \\
\hline & $\begin{array}{c}0 \\
\text { week }\end{array}$ & $\begin{array}{c}4 \\
\text { Weeks }\end{array}$ & \begin{tabular}{|c|}
0 \\
week
\end{tabular} & $\begin{array}{c}4 \\
\text { weeks }\end{array}$ & $\begin{array}{c}\mathbf{0} \\
\text { week }\end{array}$ & $\begin{array}{c}4 \\
\text { weeks }\end{array}$ & $\begin{array}{c}0 \\
\text { Week }\end{array}$ & $\begin{array}{c}4 \\
\text { weeks }\end{array}$ & $\begin{array}{c}0 \\
\text { week }\end{array}$ & $\begin{array}{c}4 \\
\text { weeks }\end{array}$ & \begin{tabular}{|c|}
$\mathbf{0}$ \\
week
\end{tabular} & $\begin{array}{c}4 \\
\text { weeks }\end{array}$ & \begin{tabular}{|c|}
$\mathbf{0}$ \\
week
\end{tabular} & $\begin{array}{c}4 \\
\text { weeks }\end{array}$ \\
\hline G1 & $\begin{array}{l}91.00 \pm \\
0.139^{c}\end{array}$ & $\begin{array}{l}97.00 \pm \\
0.139^{\mathrm{d}}\end{array}$ & $\begin{array}{l}71.00 \pm \\
0.212^{\mathrm{c}}\end{array}$ & $\begin{array}{l}72.00 \pm \\
0.354^{\mathrm{e}}\end{array}$ & $\begin{array}{l}43.67 \pm \\
0.009^{\mathrm{d}}\end{array}$ & $\begin{array}{l}44.50 \pm \\
0.142^{\mathrm{e}}\end{array}$ & $\begin{array}{l}19.33 \pm \\
0.005^{a}\end{array}$ & $\begin{array}{l}19.83 \pm \\
0.005^{\mathrm{a}}\end{array}$ & $\begin{array}{l}42.67 \pm \\
0.009^{c}\end{array}$ & $\begin{array}{l}42.77 \pm \\
0.162^{\mathrm{d}}\end{array}$ & $\begin{array}{l}8.73 \pm \\
0.005^{c}\end{array}$ & $\begin{array}{l}8.90 \pm \\
0.071^{\mathrm{e}}\end{array}$ & \begin{tabular}{|c|}
$307.00 \pm$ \\
$0.217^{c}$
\end{tabular} & $\begin{array}{r}308.33 \pm \\
0.707^{\mathrm{f}}\end{array}$ \\
\hline G2 & $\begin{array}{c}130.00 \pm \\
0.125^{\mathrm{b}}\end{array}$ & $\begin{array}{c}151.00 \pm \\
0.125^{\mathrm{c}}\end{array}$ & & $\begin{array}{c}138.00 \pm \\
0.225^{\mathrm{b}}\end{array}$ & $\begin{array}{l}75.00 \pm \\
0.284^{c}\end{array}$ & $\begin{array}{l}199.67 \pm \\
0.25^{\mathrm{b}}\end{array}$ & $\begin{array}{l}17.00 \pm \\
0.282^{\mathrm{b}}\end{array}$ & $\begin{array}{l}13.33 \pm \\
0.005^{\text {bcd }}\end{array}$ & & $\begin{array}{l}85.07 \pm \\
0.301^{\mathrm{b}}\end{array}$ & & $\begin{array}{l}35.87 \pm \\
0.009^{\mathrm{b}}\end{array}$ & & \begin{tabular}{|c|}
$556.17 \pm$ \\
$1.323^{\mathrm{b}}$
\end{tabular} \\
\hline G3 & $\begin{array}{r}332.00 \pm \\
1.414^{\mathrm{a}}\end{array}$ & $\begin{array}{c}326.00 \pm \\
0.707^{\mathrm{a}} \\
\end{array}$ & $\begin{array}{c}116.00 \pm \\
0.139^{\mathrm{a}} \\
\end{array}$ & $\begin{array}{c}171.00 \pm \\
0.225^{\mathrm{a}} \\
\end{array}$ & $\begin{array}{l}91.50 \pm \\
0.354^{\mathrm{b}}\end{array}$ & $\begin{array}{r}245.83 \pm \\
0.009^{\mathrm{a}}\end{array}$ & $\begin{array}{l}15.00 \pm \\
0.707^{c}\end{array}$ & $\begin{array}{c}10.33 \pm \\
0.120^{\mathrm{e}} \\
\end{array}$ & $\begin{array}{l}79.45 \pm \\
1.025^{\mathrm{a}}\end{array}$ & $\begin{array}{c}108.35 \pm \\
0.459^{\mathrm{a}}\end{array}$ & $\begin{array}{l}22.83 \pm \\
0.474^{\mathrm{a}} \\
\end{array}$ & $\begin{array}{l}54.83 \pm \\
0.121^{\mathrm{a}} \\
\end{array}$ & $\begin{array}{c}425.17 \pm \\
0.177^{\mathrm{a}} \\
\end{array}$ & $\begin{array}{c}701.33 \pm \\
0.707^{\mathrm{a}} \\
\end{array}$ \\
\hline G4 & $\begin{array}{l}338.00 \pm \\
1.414^{\mathrm{a}} \\
\end{array}$ & $\begin{array}{c}160.00 \pm \\
0.707^{\mathrm{c}} \\
\end{array}$ & \begin{tabular}{|c|}
$116.00 \pm$ \\
$0.212^{\mathrm{a}}$ \\
\end{tabular} & $\begin{array}{l}88.00 \pm \\
0.707^{\mathrm{d}}\end{array}$ & $\begin{array}{r}123.17 \pm \\
5.069^{\mathrm{a}}\end{array}$ & $\begin{array}{l}74.50 \pm \\
0.354^{\mathrm{d}}\end{array}$ & $\begin{array}{l}15.75 \pm \\
0.003^{\mathrm{c}}\end{array}$ & $\begin{array}{l}16.00 \pm \\
0.141^{\mathrm{b}}\end{array}$ & $\begin{array}{l}75.78 \pm \\
1.803^{\mathrm{a}}\end{array}$ & $\begin{array}{l}57.43 \pm \\
0.005^{c}\end{array}$ & $\begin{array}{l}24.63 \pm \\
1.153^{\mathrm{a}}\end{array}$ & $\begin{array}{l}14.90 \pm \\
0.007^{\mathrm{d}}\end{array}$ & \begin{tabular}{|l|}
$441.67 \pm$ \\
$4.008^{\mathrm{a}}$ \\
\end{tabular} & \begin{tabular}{|c|}
$329.33 \pm$ \\
$0.500^{\mathrm{e}}$ \\
\end{tabular} \\
\hline G5 & $\begin{array}{l}335.00 \pm \\
0.707^{\mathrm{a}}\end{array}$ & $\begin{array}{c}208.00 \pm \\
0.707^{\mathrm{b}}\end{array}$ & \begin{tabular}{rl|}
$120.00 \pm$ \\
$1.414^{\mathrm{a}}$
\end{tabular} & \begin{tabular}{|c|}
$111.00 \pm$ \\
$0.707^{\mathrm{c}}$
\end{tabular} & $\begin{array}{r}115.50 \pm \\
4.596^{\mathrm{a}}\end{array}$ & $\begin{array}{l}100.33 \pm \\
0.474^{\text {cd }}\end{array}$ & $\begin{array}{l}16.00 \pm \\
0.141^{c}\end{array}$ & $\begin{array}{l}12.58 \pm \\
0.361^{\text {cde }}\end{array}$ & $\begin{array}{l}84.36 \pm \pm \\
3.790^{\mathrm{a}}\end{array}$ & $\begin{array}{l}81.24 \pm \\
0.002^{\mathrm{b}}\end{array}$ & $\begin{array}{l}23.10 \pm \\
0.283^{\mathrm{a}}\end{array}$ & $\begin{array}{l}20.07 \pm \\
0.005^{c}\end{array}$ & \begin{tabular}{|l|}
$430.67 \pm$ \\
$3.056^{\mathrm{a}}$
\end{tabular} & $\begin{array}{r}400.00 \pm \\
0.707^{\mathrm{d}}\end{array}$ \\
\hline G6 & $\begin{array}{l}339.00 \pm \\
1.414^{\mathrm{a}}\end{array}$ & \begin{tabular}{|c|}
$157.00 \pm$ \\
$0.707^{\mathrm{c}}$
\end{tabular} & $\begin{array}{c}119.00 \pm \\
1.141^{\mathrm{a}}\end{array}$ & $\begin{array}{l}92.00 \pm \\
0.707^{\mathrm{d}}\end{array}$ & $\begin{array}{l}116.67 \pm \\
2.355^{\mathrm{a}}\end{array}$ & $\begin{array}{l}72.00 \pm \\
0.707^{d}\end{array}$ & & & & $\begin{array}{l}61.60 \pm \\
0.006^{c}\end{array}$ & & $\begin{array}{l}14.40 \pm \\
0.071^{d}\end{array}$ & & \begin{tabular}{|c|}
$324.83 \pm$ \\
$0.707^{\mathrm{e}}$
\end{tabular} \\
\hline G7 & $\begin{array}{l}336.00 \pm \\
0.707^{\mathrm{a}} \\
\end{array}$ & $\begin{array}{c}313.00 \pm \\
0.707^{\mathrm{a}} \\
\end{array}$ & $\begin{array}{r}122.00 \pm \\
2.828^{\mathrm{a}} \\
\end{array}$ & \begin{tabular}{|c|}
$120.00 \pm$ \\
$0.707^{c}$ \\
\end{tabular} & $\begin{array}{r}120.17 \pm \\
2.241^{\mathrm{a}} \\
\end{array}$ & $\begin{array}{c}111.67 \pm \\
0.229^{c} \\
\end{array}$ & $\begin{array}{l}16.15 \pm \\
0.004^{\mathrm{a}}\end{array}$ & $\begin{array}{l}11.58 \pm \\
0.004^{\mathrm{de}}\end{array}$ & $\begin{array}{l}82.70 \pm \\
2.616^{\mathrm{a}} \\
\end{array}$ & $\begin{array}{l}86.48 \pm \\
0.001^{\mathrm{b}} \\
\end{array}$ & $\begin{array}{l}23.92 \pm \\
0.006^{\mathrm{a}} \\
\end{array}$ & $\begin{array}{l}22.12 \pm \\
0.071^{c}\end{array}$ & \begin{tabular}{|c|}
$440.17 \pm$ \\
$2.121^{\mathrm{a}}$ \\
\end{tabular} & $\begin{array}{c}421.00 \pm \\
0.707^{c} \\
\end{array}$ \\
\hline G8 & $\begin{array}{l}337.00 \pm \\
0.707^{\mathrm{a}}\end{array}$ & $\begin{array}{c}228.00 \pm \\
0.707^{\mathrm{b}}\end{array}$ & $\begin{array}{c}122.00 \pm \\
2.828^{\mathrm{a}}\end{array}$ & $\begin{array}{r}112.00 \pm \\
0.707^{\mathrm{c}}\end{array}$ & $\begin{array}{c}117.33 \pm \\
0.707 \\
1.887^{\mathrm{a}}\end{array}$ & $\begin{array}{l}102.00 \pm \\
0.707 c^{d}\end{array}$ & $\begin{array}{l}15.83 \pm \\
0.163^{\mathrm{c}}\end{array}$ & $\begin{array}{l}12.88 \pm \\
0.008^{\text {cde }}\end{array}$ & $\begin{array}{l}82.37 \pm \\
2.383^{\mathrm{a}}\end{array}$ & $\begin{array}{l}79.05 \pm \\
0.317^{\mathrm{b}}\end{array}$ & $\begin{array}{l}23.47 \pm \\
0.375^{\mathrm{a}}\end{array}$ & $\begin{array}{l}20.40 \pm \\
0.006^{c}\end{array}$ & $\begin{array}{r}432.00 \pm \\
2.828^{\mathrm{a}}\end{array}$ & $\begin{array}{r}401.17 \pm \\
0.707^{\mathrm{d}}\end{array}$ \\
\hline LSDat5\% & 7.53872 & 1.63059 & 5.67786 & 1.33465 & 12.6567 & 16.2996 & 0.30253 & 2.969836 & 7.79275 & 11.00648 & 0.82656 & 3.280381 & 9.42009 & 5.85084 \\
\hline
\end{tabular}
G1: Basal diet control, G2: HFD control, G3: HFD diabetic rats, G4: HFD diabetic + 0.015\% capsaicin, G5: HFD diabetic + 1\% Serrano pepper, G6: HFD diabetic $+2 \%$

Serrano pepper, G7: HFD diabetic + 1\% Fresno Pepper and G8: HFD diabetic + 2\% Fresno

\section{References}

[1] Anthony, O.E., Ese, A.C. and Lawrence, E.O. Regulated Effects of Capsicum frutescens Supplemented Diet (C.F.S.D) on Fasting Blood Glucose Level, Biochemical Parameters and Body Weight in Alloxan Induced Diabetic Wistar Rats. British Journal of Pharmaceutical Research. 3 (3): 496-507, 2013.

[2] Association of Official Agricultural Chemists, "Official Method of Analysis,” 17 th Edition, AOAC, USA: Washington, 1995.

[3] Association of Official Agricultural Chemists, "Official Method of Analysis,” 17 th Edition, AOAC, USA: Washington, 2000.

[4] Association of Official Agricultural Chemists, "Official Method of Analysis,” 17 th Edition, AOAC, USA: Washington, 2002.

[5] Association of Official Agricultural Chemists, "Official Method of Analysis,” 2nd Edition, AOAC, USA: Washington, 2005.

[6] Bonnie Plants. Fresno Chili Hot Pepper. Available: http://bonnieplants.com/products/vegetables/peppers/fresno-chilihot-pepper. 2014.

[7] Chaiyasit, K., Khovidhunkit, W., and Wittayalertpanya, S.. Pharmacokinetic and the effect of capsaicin in Capsicum frutescens on decreasing plasma glucose level. Journal of the medical Association of Thailand. 92 (1), 108-113. 2009.

[8] Dave, D., and Paul, W. B. The Complete Chile Pepper Book: A Gardener's Guide to Choosing, Growing, Preserving, and Cooking. Portland, Oregon: Timber Press. 2009.

[9] Di Scala, K. and Crapiste, G. Drying kinetics and quality changes during drying of red pepper. LWT-Food Science and Technology 41 (5): 789-795.2008.

[10] Esayas, K., Shimelis, A., Ashebir, F., Negussie, R., Tilahun, B., \& Gulelat, D. Proximate composition, mineral content and anti- nutritionalfactors of some capsicum (capsicum annum) varieties grown in Ethiopia. Bulletin of the Chemical Society of Ethiop, 25 (3), 451-454. 2011.

[11] Famurewa, J.A.V. Oluwamukomi, M.O. and Adenuga, A.L. Dehydration of osmosised red bell pepper (Capsicum annum). Research Journal of Biological Sciences. 1 (1-4): 36-39, 2006.

[12] Giuffrida, D., Dugo, P., Torre, P., Bignardi, C., Cavazza, A., Corradini,C., and Dugo, G. Characterization of 12 Capsicum varieties by evaluation of their carotenoid profile and pungency determination. Food Chemistry. 140, 794-802.2013.

[13] Govindarajan, V. S. Capsicum: production, technology, chemistry and quality. III. Chemistry of the colour, aroma and pungency stimuli. Critical Reviews in Food Science and Nutrition 24: 245355. 1986.

[14] Hossain, M.A. Forced Convection Solar Drying of Chilli. Ph.D. thesis, Bangladesh Agricultural University, Mymensingh, Bangladesh. 2003.

[15] Hossain, M.A. and Bala, B.K. Drying of hot chilli using solar tunnel drier. Solar Energy. 81, 85-92. 2007.

[16] In-Kyung, K., A.M. Abd El-Aty, H.B. Shin, L. Ho-Chul, K. InSeon and S. Jea-Han. Analysis of volatile compounds in fresh healthy and diseased peppers (Capsicum annuum L.) using solvent free solid injection coupled with gas chromatographyflame ionization detector and confirmation with mass spectrometry. Journal of Pharmaceutical and Biomedical Analysis., 45: 487-494. 2007.

[17] Islam, S.M.D., and Choi, H. Dietary Red Chilli (Capsicum frutescens L.) is Insulinotropic rather than Hypoglycemic in Type 2 Diabetes Model of Rats. Phytotherapy Research. 22, 1025-1029 2008.

[18] Juangsamoot, J., Ruangviriyachai, C., Techawongstien, S. and Chanthai, S. Determination of capsaicin and dihydrocapsaicin in 
some hot chilli varieties by RP-HPLC-PDA after magnetic stirring extraction and clean up with $\mathrm{C}_{18}$ cartridge. International Food Research Journal. 19 (3): 1217-1226. 2012.

[19] Kaleemullah, S. and Kailappan, R Drying Kinetics of Red Chillies in a Rotary Dryer. Biosystems Engineering. 92 (1): 15-23. 2005.

[20] Kaleemullah, S. and Kailappan, R. Modelling of thin-layer drying kinetics of red chillies. Journal of Food Engineering. 76: 531-537. 2006.

[21] Kempaiah, R.K., Srinivasan, K. Integrity of erythrocytes of hypercholesterolemic rats during spices treatment. Molecular and Cellular Biochemistry. 236: 155-161. 2002.

[22] Kurt, N. Serrano Peppers. Available: http://cals.arizona.edu/fps/sites/cals.arizona.edu.fps/files/cotw/Ser anno_Pepper.pdf. 2012.

[23] Kostaropoulos, A.E. and Saravacos, G.D. Microwave pretreatment for sun-dried raisins. Journal of Food Science. 60, 344-347. 1995.

[24] Liang, Y.T., Tian, X., Chen, J.N., Peng, C., Ma, K.Y., Zuo, Y. Jiao, R. Lu, Y. Huang, Y. And Chen, Z. Capsaicinoids lower plasma cholesterol and improve endothelial function in hamsters. European Journal of Nutrition. 52, (1); 379-388. 2013.

[25] Manjunatha, H., and Srinivasan, K. Protective effect of curcumin, capsaicin and their combination on induced oxidation of lowdensity lipoprotein, iron-induced hepatotoxicity and carrageenaninduced inflammation in experimental rats. Federation of European Biochemical Societies Journal. 273: 4528-4537. 2006.

[26] Manjunatha, H., and Srinivasan, K. Hypolipidemic and Antioxidant Effects of Dietary Curcumin and Capsaicin in Induced Hypercholesterolemic Rats. Lipids. 42 (12): 1133-1142. 2007

[27] Maskan, A., Kaya, S. and Maskan, M. Hot air and sun drying of grape leather (pestil). Journal of Food Engineering. 54, 81-88. 2002.

[28] Monsereenusorn, S. Subchronic toxicity studies of capsaicin and capsicum in rats. Research communications in chemical pathology and pharmacology. 41: 95-100.1983.

[29] Negulesco, J.A., Noel, S.A., Newman, H.A., Naber, E.C., Bhat, H.B., and Witiak, D.T. Effect of pure capsaicinoids (capsaicin and dihydrocapsaicin) on plasma lipids and lipoprotein concentrations of turmey poults. Atherosclerosis. 64: 85-90. 1987.

[30] Negulesco, J.A., Murnane, M. Decreased total serum myocardial and aortic cholesterol levels following capsaicin treatment. IRCS journal of medical science 10:446-447. 1982

[31] Oboh, G., Ademiluyi, A.O. and Faloye, Y.M. effect of combination on the antioxidant and inhibitory properties of tropical pepper varieties against $\alpha$-amylase and $\alpha$-alucosidase activities: in vitro. Journal of Medicinal Food. 10

[32] Ozgur1. M., Ozcan, T., Akpinar-Bayizit, A., and Yilmaz-Ersan, L. Functional compounds and antioxidant properties of dried green and red peppers. African Journal of Agricultural Research. 6 (25), 5638-5644. 2011.

[33] Pino, P., E. Sauri-Duch and R. Mabot, Change in volatile compounds of Habanero chile pepper (Capsicum Chinense Jack. Cv. Habanero) at two ripening stages. Journal. of Food Chemistry. 94: 394-396. 2006

[34] Prasad, B.C.N., Kumar, V., Gururaj, H.B., Parimalan, R., Giridhar,P., and Ravishankar, G.A. Characterization of capsaicin synthase and identification of its gene(cys1) for pungency factor capsaicin in pepper (Capsicum sp.). Proceedings of the National Academy of Sciences, 103, 13315-13320. 2006.
[35] Reyes-Escogido, M. de L., Gonzalez-Mondragon, E. G., \& Vazquez-Tzompantzi, E. Chemical and pharmacological aspects of capsaicin. Molecules. 16, 1253-1270. 2011.

[36] Rozin, P., Mark, M., \& Schiller, D. The role of desensitization to capsaicin in chili pepper ingestion and preference. Chemical Senses, 6, 23-31.1981.

[37] Sambaiah, K., Satyanarayana, M.N. Hypocholesterolemic effect of red pepper and capsaicin. Indian Journal of Experimental Biology 18: 898-899.1980.

[38] Sambaiah, K., Satyanarayana, M.N., and Rao, M.V.L. Effect of red pepper (chilli) and capsaicin on fat absorption and liver fat in rats. Nutrition Reports International 18: 521-529. 1978.

[39] Sarker, M. S. H., Hasan, S. M. K., Aziz, M. G., Islam, M. T., S. Azam1, M. R., Roy, S. and Ibrahim, M. N. The Effect of Processing Treatments on the Shelf Life and Nutritional Quality of Green Chilli (Capsicum annuum L.) Powder. Pertanika Journal of Tropical Agricultural Science. 35 (4): 843-852. 2012.

[40] Scoville, W.L. Note on Capsicum. Journal of the American Pharmacists Association. 453-454. 1912.

[41] Srinivasan, K., Sambaiah, K., and Chandrasekhara, N. Spices as beneficial hypolipidemic food adjuncts: a review. Food Reviews International. 20: 187-220. 2004.

[42] Toontom, N., Meenune, M., Posri, W. and Lertsiri, S. Effect of drying method on physical and chemical quality, hotness and volatile flavour characteristics of dried chilli. International Food Research Journa.l 19 (3): 1023-103. 2012.

[43] Topuz, A. The effects of varying gamma radiation doses and storage on some chemical, microbiological and sensorial quality of grinded red pepper (Capsicum annum L.). PhD Thesis, Akdeniz Institute of Science, Food Science and Technology, Antalya. 2002.

[44] Topuz, A. and Ozdemir, F. Influence of gamma irradiation and storage on the capsaicinoids of sun-dried and dehydrated paprika. Food Chemistry. 86: 509-515. 2004.

[45] Tunde-Akintunde, T.Y. Effect of pretreatment on drying time and quality of chilli pepper. Journal of Food Processing and Preservation. 34. 595-608. 2010.

[46] Tundis, R., Loizzo, M.R., Menichini, F., Bonesi, M., Conforti, F. De Luca, D., and Menichini, F. Comparative study on the chemical composition, antioxidant properties and hypoglycaemic activities of two Capsicum annuum L. cultivars (acuminatum small and cerasiferum). Plant Food for Human Nutrition, 66 (3), 261269. 2011.

[47] Tundis, R., Loizzo, M.R., Menichini, F., Bonesi, M., Conforti, F., De Luca, D., and Menichini, F. Air-dried Capsicum annuum Var. acuminatum medium and big: Determination of bioactive constituents, antioxidant activity and carbohydrate-hydrolyzing enzymes inhibition. Food Research International. 45, 170-175. 2012.

[48] Wall, M.M. and Bosland, P.W. The shelf-life of chillies and chilli containing products. In Charalambous, G., (Ed). Shelf Life Studies of Food and Beverages. 487-500. 1993.

[49] WHO. World Health and Organization. Prevalence data of diabetes worldwide. 2009.

[50] Yaldiz, G., Ozguven, M. and Sekeroglu. N. Variation in capsaicin contents of different Capsicum species and lines by varying drying parameters. Industrial Crops and Products. 32: 434-438. 2010.

[51] Yao, J., M.G. Nair and A. Chandra, Supercritical carbon dioxide extraction of scotch bonnet (Capsicum annum) pepper and quantification of capsaicin and dihydrocapsaicin. Journal of Agriculture and Food Chemistry. 42: 1303-1305. 1994. 